\title{
An optimal method for generating stable vancomycin heteroresistance and intermediate susceptibility in methicillin-resistant Staphylococcus aureus blood isolates under in-vitro vancomycin pressure
}

\author{
Riad Khatib, Jinson Jose, Leonard B Johnson, Kathleen Riederer, Stephen Shemes \\ Department of Internal Medicine, St John Hospital and Medical Center, Grosse Pointe Woods, MI USA
}

\begin{abstract}
Objectives: The relevance of vancomycin intermediately-susceptible (VISA) and hetero-resistant (hVISA) methicillin-resistant Staphylococcus aureus (MRSA) remains uncertain because of their low frequency. In vitro attempts to generate reduced susceptibility have been inconsistent. We describe a simple method for generating VISA/hVISA.
\end{abstract}

Materials and methods: Twenty-four SCCmec type II and IV MRSA blood isolates plus USA100 and USA300 controls were cultured (107 CFU/ml) in BHI broth with 0,2 and $3 \mathrm{mg} / \mathrm{L}$ vancomycin for 10 days followed by 10 days vancomycin-freepassage. We monitored vancomycin minimum inhibitory concentration (MIC; Etest) and population analysis profile-area under the curve (PAP-AUC) ratios of tested isolate-Mu3 during and after vancomycin pressure (VP). PAP-AUC ratios $<0.9$, 0.9-1.3 and >1.3 were considered consistent with susceptible, hVISA and VISA, respectively.

Results: VP at $2 \mathrm{mg} / \mathrm{L}$ (VP-2) increased MIC to $3 \mathrm{mg} / \mathrm{L}$ in 20 (83.3\%) isolates and raised PAP-AUC ratio to hVISA ( $\mathrm{n}=18 ; 75.0 \%$ ) and VISA (six; 25.0\%) ranges. VP-3 increased MIC to 3 and $4 \mathrm{mg} / \mathrm{L}$ in 19 (79.2\%) and three (12.5\%) isolates, respectively and raised PAP-AUC ratio to hVISA $(n=3 ; 12.5 \%)$ and VISA $(n=19 ; 79.2 \%)$ ranges. SCCmec IV isolates had lower pre-exposure PAP-AUC ratios $(0.48 \pm 0.14$ vs. $0.69 \pm 0.10 ; p<0.001)$ and lower MIC $(1.6 \pm 0.2$ vs. $1.8 \pm 0.2 \mathrm{mg} / \mathrm{L} ; \mathrm{p}=0.1)$ but MIC rise and VISA/ hVISA emergence was comparable. MIC and PAP-AUC ratio rises were stable in 20/22 isolates during drug-free passages.

Conclusions: VISA/hVISA readily emerges among MRSA SCCmec type II and IV isolates under VP. VP at the MIC level generates hVISA while pressure at slightly higher level results in the VISA phenotype. J Microbiol Infect Dis 2012; 2(4): 129-134

Key words: Staphylococcus aureus; heteroresistance; glycopeptides; resistance; bacteremia.

\section{In-vitro vankomisin baskısı altındaki metisilin-dirençli Staphylococcus aureus kan izolatlarında stabil vankomisin heterorezistans ve orta derecede duyarlılık oluşturmak için uygun bir yöntem}

\section{ÖZET}

Amaç: Vankomisine orta derecede duyarlı (VISA) ve hetero-dirençli (hVISA) metisiline dirençli Staphylococcus aureus (MRSA) kökenlerinin nispeten az görülmesi nedeniyle önemleri konusundaki belirsizlikler sürmektedir. İnvitro ortamda azalmış duyarlılık oluşturmak için yapılan girişimlerden de tutarsız sonuçlar alınmıştır. Biz VISA/hVISA üretmek için basit bir yöntem tarif ettik.

Gereç ve yöntem: Yirmi dört SCCmec tip II ve IV MRSA kan izolatı ile birlikte USA100 ve USA300 kontrol kökenleri 10 gün süreyle 0,2 ve $3 \mathrm{mg} / \mathrm{L}$ vankomisin içeren brain-heart infüzyon sıvı besiyerine (107 colony-forming-unit/ml) ekildi, 10 gün sonra vankomisinsiz ortama ekim yapıldı. Mu3'ün (bilinen bir hVISA kontrolü) vankomisin minimum inhibitör konsantrasyonu (MİK; E test) ve popülasyon analiz profili-eğri altında kalan alan oranı (PAP-AUC oranı) izlendi. PAP-AUC-oranı 0,9 ise duyarlı, 0,9-1,3 ise hVISA ve $>1$ ise VISA olarak kabul edildi.

Bulgular: 2 mg/L vancomycin baskısı (VP-2) 20 izolatta $(\% 83,3)$ vankomisin MIC değerini 3 mg/L'ye, PAP-AUC/oranını 18'inde $(\% 75,0)$ hVISA'ya ve altısında (\%25,0) VISA aralığına yükseltti. VP-3, vancomycin MIC değerini 19 izolatta (\%79,2) 3 mg/L'ye ve üç izolatta (12,5\%) 4 mg/L'ye, PAP-AUCoranını da üçünde $(\% 12,5)$ hVISA ve 19'unda $(\% 79,2)$ VISA aralığına yükseltti. SCCmec IV kökenleri daha düşük PAP-AUC/oranına $(0,48 \pm 0,14$ 'e karşılık 0,69 $\pm 0,10 ; p<0,001)$ ve hafif düşük vankomisin MIC $(1,6 \pm$ 0,2 vs. $1,8 \pm 0,2 \mathrm{mg} / \mathrm{L} ; \mathrm{p}=0,1$ ) değerine sahip iken hVISA/VISA kökenlerinde yüksekti. İlaçSız pasajlarda MIC ve PAP-AUC-oranı artışı 22 kökenin 20'sinde stabil kaldı.

Sonuç: VISA/hVISA kolayca MRSA SCCmec tip II ve IV izolatlarda VP iler kolayca oluşmaktadır. MIC seviyesinde VP uygulaması ile hVISA üretilirken biraz daha yüksek seviyedeki baskı VISA fenotipi ile sonuçlanmaktadır.

Anahtar kelimeler: Staphylococcus aureus; heterorezistans; glikopeptitler; direnç; bakteriemi

Correspondence: Riad Khatib, MD, St John Hospital and Medical Center 19251 Mack Avenue, Suite 340, Grosse Pointe Woods, MI USA Fax: (313)343-7840 Email: riad.khatib@stjohn.org

Received: 06 July, 2012 Accepted: 16 September, 2012

Copyright (C) Journal of Microbiology and Infectious Diseases 2012, All rights reserved 


\section{INTRODUCTION}

Reduced susceptibility to vancomycin among methicillin-resistant Staphylococcus aureus (MRSA) is an emerging challenge..$^{1-8}$ Isolates with intermediate susceptibility (VISA) or minimum inhibitory concentration (MIC) at the higher end of the susceptible range $(2 \mathrm{mg} / \mathrm{L})$ are increasingly reported worldwide. 5,7 Additionally, strains with heterogeneous intermediate resistance (hVISA) account for a variable percentage of susceptible isolates, though their relevance remains controversial. ${ }^{1-4,6,8}$ The factors that lead to the emergence of hVISA and VISA phenotypes are unclear but numerous studies have associated it with vancomycin exposure. ${ }^{6,9-13}$ Nearly all isolates with reduced susceptibility were recovered from vancomycin-treated patients. ${ }^{9-14}$ Additionally, less susceptible populations of MRSA were detected in an in-vivo rat model of tissue cage infection when tissue bacterial load reached high level in the absence of drug exposure, implying spontaneous generation of resistant phenotypes at high inoculum. ${ }^{15}$ The emergence of resistance may be influenced by exposure dynamics. High drug concentrations, well above the MIC, may prevent or delay resistance. Sakoulas et al reported that prolonged vancomycin treatment at the current therapeutic levels did not lead to the development of reduced susceptibility in a patient with persistent bacteremia. ${ }^{12}$ Sieradzki et al, however, documented reduced susceptibility in an isolate recovered from a cardiac valve after prolonged therapy, which could have been due to sub-therapeutic vancomycin tissue level and high bacterial concentrations. ${ }^{8}$ Additional studies suggested that the development of resistance appears to be related to the strain genetic background..$^{11,16}$

In-vitro studies of isolates with reduced susceptibility often focus on cell wall characteristics, colony morphology and genetic changes associated with resistance. ${ }^{17-20}$ Attempts at generating derivatives with reduced susceptibility have met with varying success and usually involved a small number of isolates. ${ }^{21-25}$ We evaluated the effect of vancomycin pressure at concentrations near the MIC level among susceptible MRSA SCCmec type II and IV blood isolates. We were able to induce hVISA and VISA phenotypes with consistent results. These phenotypes remained stable during drug-free passage.

\section{MATERIALS AND METHODS}

The isolates: We selected 12 MRSA SCCmec type II and 12 type IV blood isolates saved at our research laboratory from prior $S$. aureus bacteremia studies in 1996 and 2006 (six isolates of both SCCmec types from each time period). ${ }^{5}$ They were isolates previously determined to have vancomycin MIC of $2 \mathrm{mg} / \mathrm{L}$ (Etest) and hVISA screen negative (Etest macromethod). They were identified as MRSA according to standard methods and preserved in skim milk at $-80^{\circ} \mathrm{C}$ until testing. Their SCCmec type was previously defined by multiplex PCR using 18 primers (Applied Biosystems, Foster City, CA) targeting SCCmec types I, II, III, IVa, IVb, IVc, IVd, V and mec A gene (internal control) as previously described. ${ }^{5}$ We included USA 100 and 300 control strains in each batch of test. All isolates and controls were typed using pulse-field-gel electrophoresis (PFGE) as previously described. ${ }^{26}$

Vancomycin challenge: We conducted a pilot study using two known fully susceptible control isolates (USA 100 and USA 300) plus Mu3 (a known hVISA control) to determine the optimum drug concentrations for generating reduced susceptibility. The concentrations tested were 0,1 , $2,3,4$, and $6 \mathrm{mg} / \mathrm{L}$. We found that visible growth was inhibited at $4 \mathrm{mg} / \mathrm{L}$ vancomycin concentration and the MIC of subcultured colonies did not change. At $1 \mathrm{mg} / \mathrm{L}$ of vancomycin, the isolates readily grew without any change in MIC. At 2 and $3 \mathrm{mg} / \mathrm{L}$ of vancomycin, we detected initial inhibition that was followed by visible growth and MIC rise during drug challenge. Therefore, we chose these concentrations for challenging our clinical isolates and the controls.

The selected isolates and controls were inoculated $\left(10^{7}\right.$ colony forming unit $\left.\{\mathrm{CFU}\} / \mathrm{ml}\right)$ into Brain Heart Infusion (BHI) broth with vancomycin concentrations of 0,2 and $3 \mathrm{mg} / \mathrm{L}$ and incubated for 10 days at $35^{\circ} \mathrm{C}$ with gentle agitation. If cultures became visually turbid, the organism concentration was reduced to $10^{7} \mathrm{CFU} / \mathrm{ml}$ every $24 \mathrm{~h}$ by centrifuging for 10 minutes at $2,000 \mathrm{~g}$, suctioning the spent broth and passing $1 \mathrm{ml}$ of a $10^{8} \mathrm{CFU} /$ $\mathrm{ml}$ suspension of ongoing MRSA challenge culture to $9 \mathrm{ml}$ of fresh BHI broth supplemented with vancomycin. The isolates were studied in three batches. Each batch included eight isolates se- 
lected equally from each SCCmec type and study year and USA100 and USA300 controls.

Stability phase: The isolates were cultured and serially passed for 10 consecutive days on vancomycin-free Tryptic Soy Agar (TSA) to assess the stability of the observed changes.

Microbiologic tests: Vancomycin MIC and hVISA screening were performed at baseline and every two days during vancomycin challenge and stability passages. Vancomycin MIC was measured by the Etest method (AB bioMerieux; Solna, Sweden) according to manufacturer's instructions. Screening for hVISA phenotype was done by the Etest macromethod (AB Biodisk) according to manufacturer's instructions. Population analysis profile-area under the curve (PAPAUC) was determined according to Wootton et al with a modification as previously described. ${ }^{6,27}$ We plotted the logarithm of CFU/ml versus vancomycin concentration using Microsoft Office Excel, and geometrically calculated the area under the curve.

PAP-AUC ratio was determined for all isolates plus controls at baseline (day 0 ) and day 10 of vancomycin exposure. Additionally, PAP-AUC was reassessed for all isolates with a change in MIC or hVISA screen results at the end of vancomycin-free passage compared to the end of the exposure period. Mu3 (a known hVISA control) was included in each population test. The ratio of PAP-AUC of tested isolate/average PAP-AUC of Mu3 control was measured and stratified into VISA (>1.3), hVISA (0.90-1.3) and susceptible $\operatorname{MRSA}(<0.90)$, ranges. ${ }^{6,27}$

Statistical methods: Chi square and Student's t-tests were used to assess the significance of differences in categorical and continuous variables, respectively. All statistical tests were performed using the computer software SPSS release 12. A $p$ value $<.05$ was considered to indicate statistical significance.

\section{RESULTS}

Baseline vancomycin MICs were $1.5-2 \mathrm{mg} / \mathrm{L}$ for all isolates and USA 100 and USA 300 controls which were within \pm 1 gradient difference from the previous Etest MIC.8 Baseline PAP-AUC ratios were significantly lower in SCCmec type IV compared with type II $(0.48 \pm 0.14$ vs. $0.69 \pm 0.10$; $\mathrm{p}<0.001)$ and USA 300 vs. USA 100 (0.41 vs. $0.71)$.
PFGE typing of SCCmec II isolates revealed an identical cluster of eight isolates indistinguishable from USA100, two similar isolates related to USA100 and two isolates each with a unique pattern. SCCmec IV typing revealed three PFGE clusters and three unique patterns. One cluster ( $n=3$ isolates) was indistinguishable from USA300. A second cluster of three isolates was related to USA300. The third cluster of three isolates was unrelated to USA300.

Under $2 \mathrm{mg} / \mathrm{L}$ vancomycin pressure, all isolates grew readily. Vancomycin MIC increased to $3 \mathrm{mg} / \mathrm{L}$ in $20(83.3 \%)$ isolates with equal number of SCCmec type II and IV (figure 1a). Time-to$\mathrm{MIC}$ rise was $2.7 \pm 1.3 \mathrm{~d}$ for SCCmec type II and $2.0 \pm 0 d$ for SCCmec type IV ( $p=0.06)$. PAP-AUC ratio increased to hVISA and VISA ranges in 18 $(75.0 \%)$ and six $(25.0 \%)$ instances, respectively (Figure 2). PAP-AUC ratio increase under drug pressure was comparable in SCCmec type II and IV isolates (table 1). USA 100 MIC increased in $2 / 3$ instances and its PAP-AUC ratio increased to 1.02-1.51 (hVISA/VISA). USA 300 MIC increased in $2 / 3$ instances and its PAP-AUC ratio increased to $1.08-1.11$ (hVISA range).

Under $3 \mathrm{mg} / \mathrm{L}$ vancomycin pressure, 11/12 SCCmec II grew readily and one isolate was inhibited until day nine. In comparison, 4/12 SCCmec type IV grew readily and eight isolates were inhibited for 2-9 days (median=4.5 d). The difference in inhibition rate was significant $(p=0.005$; Yates-corrected chi-square). Vancomycin MIC increased in $22(91.7 \%)$ isolates. MIC increased to $3 \mathrm{mg} / \mathrm{L}$ in 19 isolates (11 SCCmec II plus eight SCCmec IV) and to $4 \mathrm{mg} / \mathrm{L}$ in three SCCmec type IV (Figure 1b). USA $100 \mathrm{MIC}$ increased to $3 \mathrm{mg} / \mathrm{L}$ in two batches and to $4 \mathrm{mg} / \mathrm{L}$ in one batch. USA $300 \mathrm{MIC}$ increased to $3 \mathrm{mg} / \mathrm{L}$ in one batch, $4 \mathrm{mg} / \mathrm{L}$ in another batch and $2 \mathrm{mg} / \mathrm{L}$ in the third batch from a baseline of $1.5 \mathrm{mg} / \mathrm{L}$. PAP-AUC ratio increased to hVISA and VISA ranges in three $(12.5 \%)$ and $19(79.2 \%)$ isolates, respectively. These changes were significantly higher than the changes under $2 \mathrm{mg} / \mathrm{L}$ vancomycin pressure $(p=0.03)$. Most isolates expressed hVISA phenotype (based on PAP-AUC ratio) under $2 \mathrm{mg} / \mathrm{L}$ pressure and VISA phenotype (based on MIC > $2 \mathrm{mg} / \mathrm{L}$ and PAP$A \cup C$ ratio) under $3 \mathrm{mg} / \mathrm{L}$ pressure (figure 2). The rate of hVISA and VISA emergence was comparable in SCCmec II and IV isolates (table 2). USA 100 and 300 PAP-AUC increased to VISA range (1.33-2.26) and hVISA/VISA range (1.05-2.20), 
respectively. The differences in MIC and PAPAUC ratio between baseline and the end of vancomycin 2 and $3 \mathrm{mg} / \mathrm{L}$ were significant $(p<0.001$; paired sample-t-test).

We observed the conversion of colony morphology to a smaller pinpoint morphology under 3 $\mathrm{mg} / \mathrm{L}$ vancomycin pressure in three isolates, one SCCmec type II and two type IV.

MIC rise under vancomycin pressure persisted during vancomycin-free passages in all but two isolates. USA $100 \mathrm{MIC}$ rise was stable in all batches. USA $300 \mathrm{MIC}$ rise was stable in two batches and decreased from 4 to $3 \mathrm{mg} / \mathrm{L}$ in one batch. MIC rise was independent of PFGE type among SCCmec IV isolates. The role of PFGE type in SCCmec II isolates could not be assessed because most isolates clustered into a single type.

We also examined the role of hVISA screening in detecting the emergence of reduced susceptibility using the Etest macromethod with vancomycin and teicoplanin strips. These isolates were previously determined to be hVISA-screen negative. Baseline screening in the current study yielded higher than expected readings in the tested isolates and the controls although these isolates were confirmed to be susceptible by

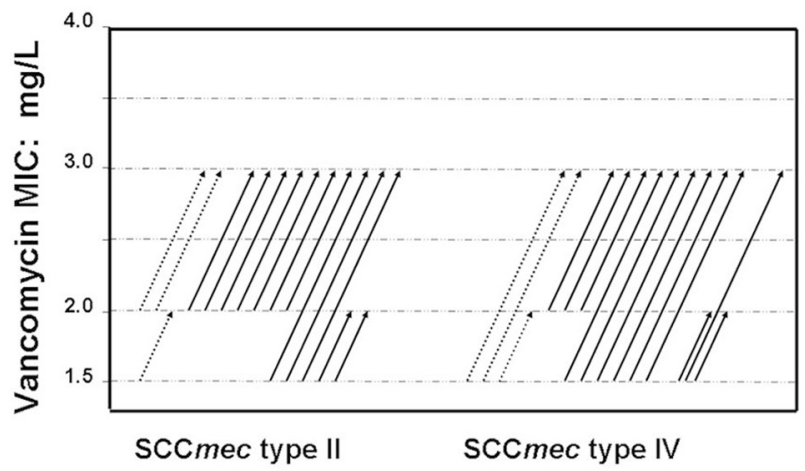

PAP-AUC analysis. This precluded us from a reliable baseline interpretation of screening results. Under vancomycin pressure, growth at vancomycin and/or teicoplanin strip concentrations two increments higher than baseline was noted in five $(22.8 \%)$ and $11(45.8 \%)$ isolates under two and three $\mathrm{mg} / \mathrm{L}$ vancomycin pressure, respectively. These screening increases persisted during drug free passages in 12 isolates and decreased in four isolates although their PAP-AUC remained in the VISA range (data not shown).

12 MRSA SCCmec type II plus USA100 12 MRSA SCCmec type IV plus USA300

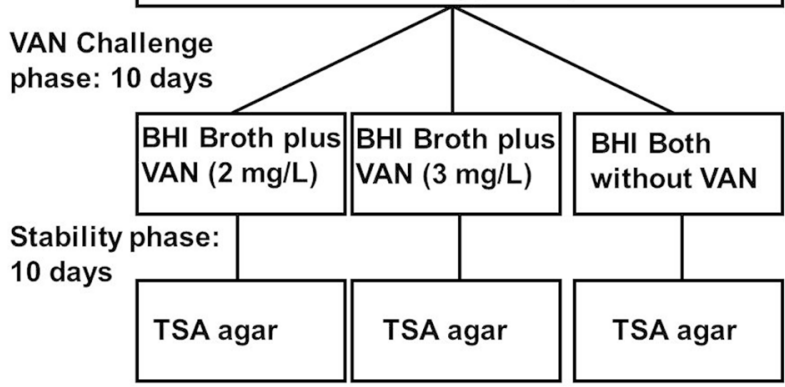

Figure 1. 1a: Vancomycin MIC changes from baseline to day 10 of vancomycin pressure at $2 \mathrm{mg} / \mathrm{L}$. $1 \mathrm{~b}$ : Vancomycin MIC changes from baseline to day 10 of vancomycin pressure at $3 \mathrm{mg} / \mathrm{L}$. Each line represents an isolate. Solid lines represent clinical isolates. Dotted lines represent USA100 and USA300 controls.

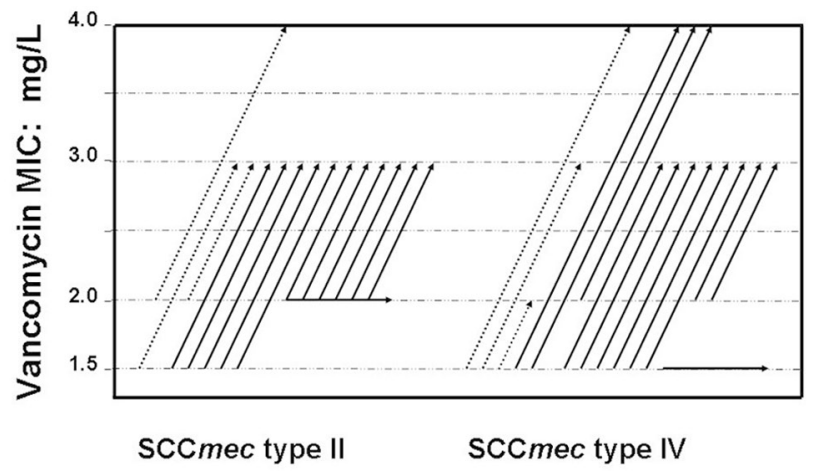

Figure 2. The rate of hVISA (shaded bars) and VISA (black bars) emergence among methicillin-resistant Staphylococcus aureus under 2 and $3 \mathrm{mg} / \mathrm{L}$ vancomycin (VAN) pressure.

\section{DISCUSSION}

The prevalence of $S$. aureus isolates with reduced susceptibility to glycopeptide antibiotics appears to be increasing. ${ }^{1,2,4,5,7,9}$ High level resistance remains rare but hVISA and VISA had been noted in many centers. ${ }^{3,5,7}$ VISA has been associated with vancomycin treatment failures. The relevance of hVISA remains uncertain but it is considered a precursor of VISA. ${ }^{3,5,28}$ The factors that contribute to the emergence of hVISA and VISA are uncertain but most isolates with hVISA and VISA phenotype were recovered from patients exposed to Vancomycin. ${ }^{6,9-13}$ Prior in-vitro attempts to generate hVISA and VISA have met with varying success. Rose et al reported decreased susceptibility among a hVISA control (Mu3) and a hVISA clinical isolate, both with van- 
comycin MIC of $2 \mathrm{mg} / \mathrm{L}$, but not with a susceptible MRSA isolates with vancomycin MIC of $0.5 \mathrm{mg} / \mathrm{L}$ during $72 \mathrm{~h}$ selection under lower vancomycin concentrations and high inoculums in an in-vitro pharmacodynamic model. ${ }^{21}$ Plipat et al generated unstable hVISA in $74 \%$ of 109 MRSA isolates in $\mathrm{BHI}$ agar containing increasing vancomycin concentrations. ${ }^{22}$ Wong et al were able to induce vancomycin resistance in 3/164 Staphylococcus aureus isolates with a $48 \mathrm{~h}$ single step selection at $4 \mathrm{mg} / \mathrm{L}$ vancomycin concentration. ${ }^{23}$ Daum et al selected less-susceptible derivatives with increasing concentrations of Vancomycin. ${ }^{24}$ Pfeltz et al were able to select resistant derivatives in $8 / 12$ strains during a 1-11 week incubation with vancomycin at $1-3 \mathrm{mg} / \mathrm{L}$ above individual strains MIC. ${ }^{23}$ Additionally, serial $10-84$ days passages of a VISA isolate (Mu50) in drug-free media led to a decrease in cell wall thickness and MIC that reverted with a one step selection at $4 \mathrm{mg} / \mathrm{L}$ Vancomycin. ${ }^{17}$

In the current study, we describe a method for generating reduced susceptibility phenotypes with consistent results. We showed that nearly all isolates plus USA 100 and USA 300 controls exhibited populations with reduced susceptibility under drug pressure. At $2 \mathrm{mg} / \mathrm{L}$ vancomycin pressure, which was at the baseline MIC level, all isolates readily grew and most isolates exhibited hVISA phenotype. Of note is the difference in baseline PAP-AUC ratio between SCCmec types II and IV which suggests more susceptible populations among type IV isolates prior to vancomycin exposure. Given the fact that SCCmec type II is a marker of healthcare-associated strains, prior exposure to vancomycin may account for the higher MIC and PAP-AUC ratio in SCCmec II.29 Under vancomycin pressure, MIC and PAPAUC ratio changes were comparable among SCCmec type II and IV isolates. Growth inhibition was noted more often among SCCmec IV isolates at $3 \mathrm{mg} / \mathrm{L}$ vancomycin pressure, but eventually, growth was noted in all isolates. A number of isolates were driven into VISA phenotype with comparable frequency in both SCCmec types. Etest MICs of the emergent isolates increased to $3 \mathrm{mg} / \mathrm{L}$, which is above the susceptibility cutoff. These MIC and PAP-AUC ratio rises remained stable for 10 days in vancomycin-free culture in most isolates. Other investigators reported reversion to a more susceptible phenotype in drug-free conditions. ${ }^{30}$ The reasons for the difference are unclear but might be related to isolate selection or drug exposure dynamics.

The high frequency of hVISA and VISA emergence in our study may be due to several factors. Our method for isolate selection and the use of high inoculum may have contributed to these results. We selected isolates at the high end of the susceptibility range. These isolates may already have a less susceptible population below the level of detection which was selected under drug pressure. Additionally, we used vancomycin pressure at or slightly above the MIC value. We chose these isolates and lower vancomycin concentrations to maximize the possibility of resistance emergence. Whether these isolates have a subpopulation with pre-existing mutations which were selected under drug pressure or that drug pressure induced resistance mutations is uncertain. We did not perform molecular assessment of pre and post exposure isolates. Inducing hVISA or VISA in isolates with lower MIC may be less successful because of complete inhibition of growth or less frequent emergence of resistance. Generating reduced susceptibility among these isolates may require a step-wise selection.

One limitation of our study is the uncertainty of prior vancomycin exposure of a given isolate. History of lack of exposure to vancomycin by a given patient may not be accurate. Furthermore, the isolate could have been acquired from a vancomycin-exposed source.

In conclusion, we describe a method for inducing hVISA and VISA phenotypes among MRSA SCCmec type II and IV blood isolates with consistent results. Drug pressure at the MIC level generates hVISA and pressure at slightly above the MIC generates VISA. The emergent variants may be used for additional studies to determine the molecular changes associated with these phenotypes.

\section{Acknowledgments}

Supported by St John Hospital Medical Education Fund.

The authors are grateful to Ms Alice Mar for editing the figures.

\section{REFERENCES}

1. Bae IG, Federspiel JJ, Miró JM, et al. Heterogeneous vancomycin-intermediate susceptibility phenotype in bloodstream methicillin-resistant Staphylococcus aureus isolates from an international cohort of patients with infective endocarditis: 
prevalence, genotype and clinical significance. J Infect Dis 2009; 200:1355-1366.

2. Fridkin SK, Hageman J, McDougal KL, et al. Vancomycin-Intermediate Staphylococcus aureus Epidemiology Study Group. Epidemiological and microbiological characterization of infection caused by Staphylococcus aureus with reduced susceptibility to vancomycin, United States, 1997-2001. Clin Infect Dis 2003; 36:429-439.

3. Khatib R, Jose J, Musta AC, et al. The relevance of vancomycin-intermediate susceptibility and heteroresistance in methicillin-resistant Staphylococcus aureus bacteremia. J Antimicrob Chem 2011; 66:1594-1599.

4. Kosowaska-shick K, Ednie LM, McGhee P, et al. Incidence and characteristics of vancomycin nonsusceptible strains of methicillin-resistant Staphylococcus aureus at Hershey medical center. Antimicrob Agent Chemother 2008; 52:4510-4513.

5. Musta AC, Riederer K, Shemes S, et al. Vancomycin MIC plus heteroresistance and the outcome of methicillin-resistant Staphylococcus aureus bacteremia: trends over 11 years. J Clin Microbiol 2009; 47:1640-1644.

6. Riederer K, Shemes S, Chase P, Musta AC, Mar A, Khatib R. Detection of intermediately vancomycin-susceptible and heterogeneous Staphylococcus aureus isolates: comparison of Etest and agar screening methods. J Clin Microbiol 2011; 49:2147-2150.

7. Rybak MJ, Leonard SN, Rossi KL, Cheung CM, Sadar HS, Jones RN. Characterization of vancomycin-heteroresistant Staphylococcus aureus from the Metropolitan Area of Detroit, Michigan, over a 22-year period (1986-2007). J Clin Microbiol 2008; 46:2950-2954.

8. Sieradzki K, Leski T, Dick J, Borio L, Tomasz A. Evolution of a vancomycin-intermediate Staphylococcus aureus strain in vivo: multiple changes in the antibiotic resistance phenotypes of a single lineage of methicillin-resistant $S$. aureus under the impact of antibiotics administered for chemotherapy. J Clin Microbiol 2003; 41:1687-1693.

9. Howden BP, Ward PB, Robson J, Morris AJ, Mayall BC, Grayson ML. Treatment outcomes for serious infections caused by methicillin-resistant Staphylococcus aureus with reduced vancomycin susceptibility. Clin Infect Dis 2004; 38:521-528.

10. Fong RK, Low J, Koh TH, Kurup A. Clinical features and treatment outcomes of vancomycin-intermediate Staphylococcus aureus (VISA) and heteroresistant vancomycin-intermediate Staphylococcus aureus (hVISA) in a tertiary care institution in Singapore. Eur J Clin Microbiol Infect Dis 2009; 28:983-987.

11. Moise PA, Forrest A, Bayer AS, Xiong YQ, Yeaman MR, Sakoulas G. Factors influencing time to vancomycin-induced clearance of non-endocarditis methicillin-resistant Staphylococcus aureus bacteremia: role of platelet microbial protein killing and agr genotypes. J Infect Dis 2010; 201:233-240.

12. Sakoulas G, Gold HS, Cohen RA, Venkataraman L, Moellering RC, Eliopoulos GM. Effects of prolonged vancomycin administration on methicillin-resistant Staphylococcus aureus (MRSA) in a patient with recurrent bacteremia. J Antimicrob Chemother 2006; 57:699-704.

13. Song JH. Emergence of Staphylococcus aureus with reduced susceptibility to vancomycin in Asia. In: LU Yichen, eds. Emerging Infections in Asia. New York: Springer, 2008; 233242.

14. Moise PA, Smyth DS, El-Fawal N, et al. Microbiological effects of prior vancomycin use in patients with methicillin-resistant Staphylococcus aureus bacteraemia. J Antimicrob Chemother 2008; 61:85-90.

15. Vaudaux $P$, Francois $P$, Berger-Bachi $B$, Lew DP. In vivo emergence of subpopulations expressing teicoplanin or vancomycin resistance phenotypes in a glycopeptide-susceptible, methicillin-resistant strain of Staphylococcus aureus. J Antimicrob Chemother 2001; 47:163-170.
16. Chui L, Ma X, Sato K, et al. Cell wall thickening is a common feature of vancomycin resistance in Staphylococcus aureus. $\mathrm{J}$ Clin Microbiol 2003; 41:5-14.

17. Sakoulas G, Eliopoulos GM, Moellering RC Jr, et al. Staphylococcus aureus accessory gene regulator (agr) group II: is there a relationship to the development of intermediate-level glycopeptide resistance? J Infect Dis 2003; 187:929-938.

18. Hanaki H, Kuwahara-Arai K, Boyle-Varva S, Daum RS, Labischinski $\mathrm{H}$, Hiramatsu K. Activated cell-wall synthesis is associated with vancomycin resistant Staphylococcus aureus clinical strains Mu3 and Mu50. J Antimicrob Chemother 1998; 42:199-209.

19. Cameron DR, Ward DV, Kostoulias $X$ et al. Serine/threonine phosphatase Stp1 contributes to reduced susceptibility to vancomycin and virulence in Staphylococcus aureus. J Infect Dis 2012; 205:1677-1687.

20. Howden BP, Davies JK, Johnsosn PDR, Stinear TP, Grayson ML. Reduced vancomycin susceptibility in Staphylococcus aureus, including vancomycin-intermediate and heterogeneous vancomycin-intermediate strains: resistance mechanisms, laboratory detection, and clinical implications. Clin Microbiol Rev 2010; 23: 99-139.

21. Rose WE, Leonard SN, Rossi KL, Kaatz GW, Rybak MJ. Impact of inoculum size and heterogeneous vancomycin-intermediate Staphylococcus aureus (hVISA) on vancomycin activity and emergence of VISA in an in-vitro pharmacodynamic model. Antimicrob Agents Chemother 2009; 53:805-807.

22. Plipat N, Livni G, Bertram H, Thompson RB Jr. Unstable vancomycin heteroresistance is common among clinical isolates of methicillin-resistant Staphylococcus aureus. J Clin Microbiol 2005; 43:2494-2496.

23. Wong SSY, Ho PL, Woo PCY, Yuen KY. Bacteremia caused by staphylococci with inducible vancomycin resistance. Clin Infect Dis 1999; 29:760-767.

24. Daum RS, Gupta S, Sabbagh R, Milewski WM. Characterization of Staphylococcus aureus isolates with decreased susceptibility to vancomycin and teicoplanin: isolation and purification of a constitutively produced protein associated with susceptibility. J Infect Dis 1992; 166:1066-1072.

25. Pfeltz RF, Singh VK, Schmidt JL, et al. Characterization of passage-selected vancomycin-resistant Staphylococcus aureus strains of diverse parental backgrounds. Antimicrob Agents Chemother 2000; 44:294-303.

26. Zafar U, Johnson LB, Hanna M, et al. Prevalence of nasal colonization among patients with community-associated methicillin-resistant Staphylococcus aureus infection and their household contacts. Infect Control Hosp Epidemiol 2007; 28:966-969.

27. Wootton M, Howe RA, Hillman R, Walsh TR, Bennett PM, MacGowan AP. A modified population analysis profile (PAP) method to detect hetero-resistance to vancomycin in Staphylococcus aureus in a UK hospital. J Antimicrob Chemother 2001; 47:399-403.

28. Howden BP, Davies JK, Johnson PDR, Stinear TP, Grayson ML. Reduced vancomycin susceptibility in Staphylococcus aureus, including vancomycin-intermediate and heterogeneous vancomycin-intermediate strains: resistance mechanisms, laboratory detection and clinical implications. Clin Microbiol Rev 2010; 23:99-139.

29. Moise PA, Smyth DS, Robinson DA, El-Fawal N, McCalla C, Sakoulas G. Genotypic and phenotypic relationships among methicillin-resistant Staphylococcus aureus from three multicenter bacteremia studies. J Antimicrob Chemother 2009; 63:873-876.

30. Bozdogan B, Ednie L, Credito K, Kosowaska K, Appelbaum PC. Derivative of a vancomycin-resistant Staphylococcus aureus strain isolated at Hershey Medical Center. Antimicrob Agent Chemother 2004; 48:4762-4765. 